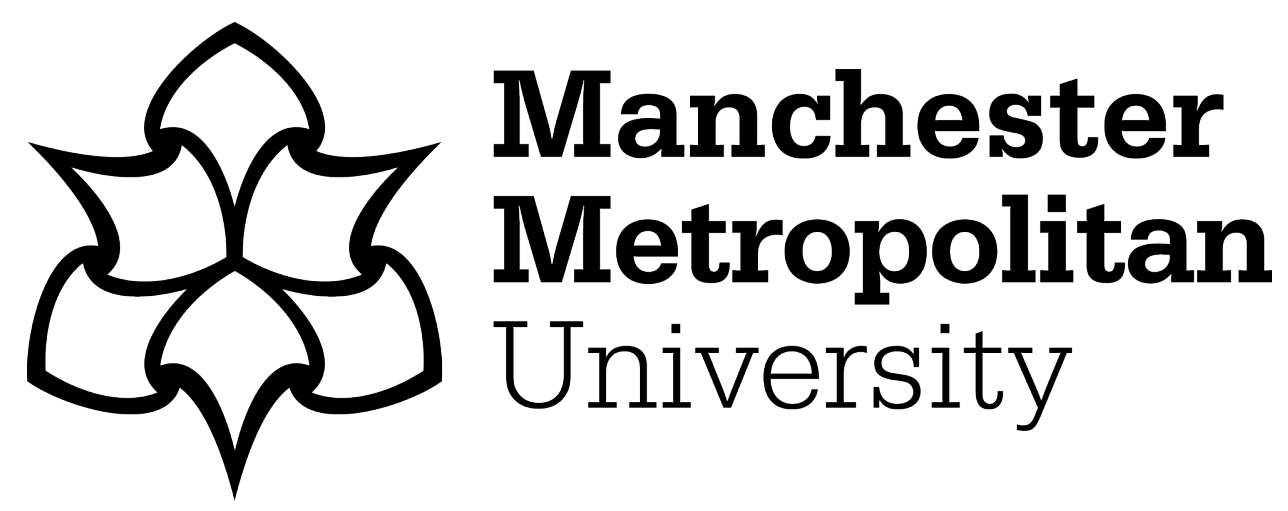

Sellar, S ORCID logoORCID: https://orcid.org/0000-0002-2840-5021 and Lingard, B (2018) International large-scale assessments, affective worlds and policy impacts in education. International Journal of Qualitative Studies in Education, 31 (5). pp. 367-381. ISSN 0951-8398

Downloaded from: https://e-space.mmu.ac.uk/623371/

Version: Accepted Version

Publisher: Taylor \& Francis

DOI: https://doi.org/10.1080/09518398.2018.1449982

Please cite the published version 


\section{International large-scale assessments, affective worlds and policy impacts in education}

Word count: 8881 words (including abstract, title and keywords)

Page count: 17

\section{Authors:}

Sam Sellar (corresponding author)

Manchester Metropolitan University

Brooks Building, 53 Bonsall Street, Manchester M15 6GX

s.sellar@mmu.ac.uk

+44 (0) 1612472078

Dr Sam Sellar is Reader in Education Studies at Manchester Metropolitan University. Sam's research focuses on intersections between education policy, governance and data. He is currently an associate editor of Discourse: Studies in the Cultural Politics of Education and was formerly an editor of Critical Studies in Education. Sam is co-author of Globalizing Educational Accountabilities (2016, Routledge) and co-editor of National testing in schools: An Australian assessment (2016, Routledge).

Bob Lingard

School of Education

The University of Queensland

Brisbane QLD 4072

Australia

r.lingard@uq.edu.au

$+61733657343$

Bob Lingard is a professorial research fellow in the School of Education at The University of Queensland, Brisbane, Australia. He researches within the sociology of education and policy sociology in education. His most recent books include, the co-authored Globalizing Educational Accountabilities (Routledge, 2016), the co-edited National Testing in Schools (Routledge, 2016), the co-edited Handbook of Global Education Policy (Wiley-Blackwell, 2016) and the sole-authored, Politics, Policies and Pedagogies in Education (Routledge, 2014). 


\title{
International large-scale assessments, affective worlds and policy impacts in education
}

\begin{abstract}
This paper examines the impact of the Organisation for Economic Cooperation and Development's (OECD) Programme for International Student Assessment (PISA) in two national policy contexts: Canada and Australia. Drawing on theories of globalization and affect, the paper explores 'catalyst data' and its effects in these contexts to show how affective responses to mediations of PISA performance have become important levers for policy change. Two empirical cases of the role of data in the globalization of schooling are discussed. The first case examines responses in Canada to the PISA 2012 results, which generated senses of anxiety among parents that coalesced into a view that Albertan schools faced a mathematics crisis. The second case interrogates how, since PISA 2009, a narrative about the declining quality of Australian schooling has become dominant in political discourse and in media representations. The paper compares and contrasts the affective effects of data across both contexts.
\end{abstract}

Keywords: affect, data, globalization, OECD, PISA

\section{Introduction}

This paper examines how international policy instruments have specific effects in national and subnational policy contexts. We focus on the Organisation for Economic Cooperation and Development's (OECD) Programme for International Student Assessment (PISA) and its impact in Australia and Canada. The official rationale for conducting PISA is to generate evidence that can be used to compare schooling systems based on PISA performance and to learn lessons about policy and practice from successful systems. While PISA does generate a large data set, and its measurement of reading, mathematical and scientific literacy is technically sound, the impact of PISA on policy and public perception is mediated in ways that can become quite disconnected from the evidence. For example, the release of PISA data every three years generates headlines around the world that celebrate or decry the state of school systems at home and abroad. Yet the detailed and most useful secondary analyses that the OECD conducts on PISA data gets limited-if any-media coverage. Furthermore, media coverage of the initial release of results has been heavily focused on comparative performance on PISA league tables, or what has been called 'counts and comparisons' (Author, 2016). The focus is most often comparative performance on the test, as reflected by national ranking, and consideration of performance against OECD average scores, with a tendency to neglect equity issues raised by the data. Our aim in this paper is to theorise how mediations of PISA results resonate within national and sub-national public spheres, which are understood, following Berlant $(2005,2011)$, as affective worlds. Specifically, we ask why and how PISA creates public senses of crisis in relation to schooling and we argue that affect has as much effect as rational analysis of the empirical data.

Elsewhere, we have described how large-scale assessments in education produce 'catalyst data' (Author, 2013) that provoke a reaction when introduced into a particular policy context. We stress that context is important for the reception of performance on large-scale assessments and needs to be read in various ways, including through national and post-national frames. We have also considered the role of affect in the responses generated by assessment data (Author, 2015). Our interest in this paper is to develop these theorisations further, and to augment other studies of the role that affect plays in educational governance (e.g. Brøgger \& Staunæs, 2016; Ratner \& Pors, 2013; 
Staunæs, 2011), in order to understand how PISA data catalyse reactions that take on affective tones of crisis and anxiety. More specifically, we are interested in how very similar data create different reactions in different contexts, and to this end we focus on the response to PISA 2012 data in Alberta, Canada and PISA data from 2009 onwards in Australia. In both cases, PISA has provoked narratives of declining performance and the need for education reform. However, attention to the affective worlds in which PISA results generated this response in each context highlights important differences in the ways that data react with public feelings. Differences in how educational federalism works in each national context are also important, as our analysis will demonstrate.

Lauren Berlant writes that '[p]ublic spheres are always affect worlds, worlds to which people are bound, when they are, by affective projections of a constantly negotiated common interestedness' (Berlant, 2011, p. 226). We argue that schooling has become an integral part of affective worlds that, in an era of growing precarity, bind people's desire for social mobility through education and their sense of national identity, security and so on. These affective worlds mediate the reception of PISA results. Numerous studies of the mediatisation of PISA demonstrate how newspapers publicly represent comparative school system performance (Author, 2016; Takayama, Waldow \& Sung, 2014; Pons, 2011; Martens \& Niemann, 2013). PISA shocks can be precipitated when there is a mismatch between a nation's self-evaluation of the quality of its schooling systems and its performance on PISA (Ertl, 2006; Grek, 2009; Wiseman, 2013). Steiner-Khamsi (2003) speaks of 'scandalisation' as one significant affective response to poor PISA performance and Brøgger (2016) has shown how affective mechanisms facilitate 'naming and shaming' in higher education policy contexts.

We seek to build on PISA reception studies by theorising the interface between media representations of performance and the development of affective worlds that shape education reform contexts. We stress that the media do not simply represent a nation's comparative PISA performance, but also help constitute affective responses to that performance through the media's specific logics of practice (Author, 2004). Contemporary politicians are also, at least implicitly, aware that the public sphere is an affective world (Massumi, 2002) and seek to modulate affect when commenting on the nation's performance on international assessments such as PISA, as well as reading the data through their own political lenses. We also note that the OECD, through its media strategy, seeks to manage media reporting of the release of PISA results within nations as well, attempting to ensure the impact they see as desirable and effective. OECD media personnel concede that national media are mostly interested in league tables of comparative performance. Our argument is that an important site for studying the catalytic effects of data is at the interface where the narration of data, by politicians, the media and others, meets the affective worlds of various publics.

An important backdrop to our analysis is the suggestion that we are living in a 'post-truth' age in which emotion and belief can be more important than facts in shaping public opinion and voting behaviours. In this context, data are not becoming less important-indeed, the opposite is true-but are tightly interwoven with visceral experience of data representations (Lury, Parisi \& Terranova, 2012). Data perform a rhetorical function that is not always a precursor to the production of evidence and facts (Rosenberg, 2013). The value of data generated by large-scale educational assessments such as PISA can be less a matter of what the data show than what the data do: catalyse a reaction and open windows for policy reform through affective impact. Indeed, the OECD in its own rationale for PISA observes that 'evidence suggests that international pressure and 
competitive environments are more likely to diffuse a sense of ineluctability of some reforms among the various stakeholders and the public at large' (OECD, 2002: 315). Further, the OECD observes that 'experience shows that more comprehensive reforms are possible when there is a widespread recognition of the need for a change to take place' (OECD, 2002: 335). We argue that the conceptual vocabularies of affect theory can make important contributions to policy analysis in this context, particularly in relation to policy reception research, where the growth of data culture meets populist politics that rides on waves of affect and desire in a post-truth context.

The paper is organised into four main sections. Next, we introduce our theoretical framework, which draws on Lauren Berlant's analyses of public spheres as affective worlds. We then provide a methodological note, followed by two case studies of the impact of PISA 2012 in Alberta, Canada and the impact of PISA since 2009 in Australia. Our comparison of a Canadian province with the Australian national context is, in part, a manifestation of the different federalisms in the two nations. We conclude with a discussion of the comparative analysis of the two cases.

\section{Theoretical framework}

In order to examine how reporting of PISA results can produce a sense that school systems are in crisis, we synthesise a framework that combines theorisations of the changing opportunity structures of education, the existential politics of aspiration, the role of education in building national economies and identities, and the role of affect in constituting public spheres. These conceptual resources enable us to analyse the conditions in which measures and comparisons of national educational performance can generate particular types of events-'shocks'-that we understand as singular points of transformation (Deleuze, 1990), and the various mechanisms through which these events are generated, experienced and extended into public moods. A key concept for our theoretical framework is affect, understood as bodily or visceral intensity that operates in parallel with thought; a kind of relational 'thinking-feeling' (Massumi, 2011; see also Gregg \& Siegworth, 2010).

Understanding the manufacture of educational crisis requires an understanding of the hopes that bind people to education as a pathway to better lives for themselves and their children. Education has been a key mechanism of upward social mobility for the middle and lower classes. The promise of mobility through education has become central to the social contract between governments and citizens in capitalist societies (Brown, Lauder \& Ashton, 2010). However, credential inflation has also been occurring as larger numbers of people accept the promise that more learning will equal more earning (Collins, 1977; 2013). This 'opportunity bargain' runs into a problem that is 'rooted in the relationship between capitalism and democracy' (Brown, 2003, p.150). While ' $t \mathrm{t}$ ] he mass ranks of the middle classes and those from aspirational working-class families have high hopes of what the knowledge economy has to offer, fuelled by the expansion of higher education' (Brown, 2003, p.150), '[w]e have entered a period of "educational stagflation", where inflationary pressures on credentials continues, and at the same time the job market cannot create enough of the jobs that many expect' (Brown, 2003, p. 160). Brown describes this situation as an opportunity trap, which we argue places people in the affective bind of 'cruel optimism' when hopeful pursuit of social mobility by larger and larger numbers erodes the very opportunities that are promised. For Berlant (2011), cruel optimism describes 'a relation to compromised conditions of possibility' (p. 24). Understanding compromised possibilities for educational opportunity, and how these have become central to the 
social contracts that governments now make with citizens, is an important first step in understanding the senses of crisis that we analyse below.

Hopefulness about education promoted by the opportunity bargain does not simply arise from the rational calculation of interests or individual desires. Instead, it is part of a systematic existential politics, or

... the ways in which states attempt to identify and institutionalise selective meanings and understandings of human subjectivity by defining some of the fundamentals of the human condition such as: what it means to be happy, fulfilled, and contented; what constitutes essential and nonessential human needs; what processes shape the ways in which the social and cultural status of individuals and groups is defined; and what delineates the distribution of rights and responsibilities between citizens and state bureaucracies. (Raco, 2009, p. 437)

Raco argues that we have moved from the politics of expectation that characterised the post-war welfare state to a politics of aspiration that shifts responsibility onto individuals for their own social and economic wellbeing. As Rose $(1999, \mathrm{p} .161)$ notes, 'The new citizen is required to engage in a ceaseless work of training and retraining, skilling and reskilling, enhancement of credentials and preparation for a life of incessant job seeking: life is to become a continuous economic capitalization of the self'. A key element of this politics is the combination of 'definitions of the appropriate social practices and expectations of citizens and communities' with standards and measures of performance, or 'yardsticks [that] help to frame policy debates and shape broader imaginations of people and places' (Raco, 2009, p. 437). The opportunity bargain is a qualitative expectation instilled in citizens, while large-scale educational assessments have become important yardsticks of national educational and economic performance.

The impact of PISA is linked to the dominant contemporary framing of educational policy, namely a particular articulation of human capital theory (Rizvi \& Lingard, 2010). With the globalization of the economy, nations across the globe have seen the production of high quality human capital through schooling systems as the best economic policy and as insurance for the future; that is, as a way to ensure the future global competitiveness of the putative national economy. Politicians and policy makers take comparative performance on PISA as a surrogate measure or yardstick of that future. Declining performance is thus tied up with concern and uncertainty about national prosperity, about the likely future for the nation and its citizens, and thus carries a particular affective burden.

Media reports about the failure of schools at home, or the success of school systems elsewhere, readily intersect with people's sense of the educational opportunity structures available to them and their prospects for prosperous lives tied to the economic strength of the nation. The primary, and perhaps only, contact that most people have with PISA, is through headlines and stories about national performance in comparison with other countries. Dissonance can emerge when these reports challenge people's sense of the quality of their schools. Martens and Niemann (2013) argue that mediatization of PISA can produce a shock when 'a substantial gap between national selfperception and the empirical results ("perception") can be observed, and the evaluated topic is framed as crucial for state purposes ("framing")' (p. 315). In other words, when education is framed as nationally important, as it is in relation to contemporary human capital agendas, and educational 
performance is found wanting in relation to people's expectations, a public sense of crisis can emerge.

Media reports of educational crises help to coalesce the publics that register these events as a 'glitch' in educational and national (infra)structures (Berlant, 2016), and the sense of crisis can, in turn, sustain or increase demand for related media products. We understand the emergence of publics, following Stengers (2005), as an event in which groups of people coalesce around a particular problem. Stenger's development of Deweyan thinking about emergent publics, rather than a homogenous and static public, emphasises the catalysing role of knowledge in gathering people around a problem that concerns them. This process has important affective dimensions. Berlant (2005) writes that, 'insofar as the public is presumed to be identical with the polity, national publicness is a normative effect of communications that show to the public events that are already cast as constituting the collective experience of the national present' (p. 49). The spectator to such events is

... solicited to feel the impact that provides evidence that she belongs to the public constituted as a mass of spectators who see what she sees and feel what she feels, within a range of appropriate variation. ... the collective experience of social belonging privatizes her at the same time as it provides a subjective experience of participation in publicness.

We could see Anderson's (2006) concept of the nation as an 'imagined community' extended here to the idea of national public spheres as affective worlds. Appadurai (1996) has augmented Anderson's account by suggesting that information and communication technologies today allow for imagined worlds, including affective worlds, that stretch beyond and across national borders, and of course, PISA as an international assessment enables international comparisons in such an imagined world, with significance for the imagined community of the nation.

Stories about educational crisis are constituted as matters of national concern around which public moods emerge. While the opportunity bargain is made with individuals or families, and social mobility generally comes at the expense of others who do not gain the same benefits from education, the systemic failure of schools can produce a shared sense that ' $w e^{\prime}$ are losing in the competition for better qualifications and jobs, that 'our' collective future will be compromised. Here, Sara Ahmed's writing on national mood is particularly instructive. Ahmed (2014) characterises mood as a lingering feeling that 'becomes an affective lens, affecting how we are affected' (p. 14). Moods shape the conditions of encounter within affective worlds. Ahmed also describes the role of various media in producing public moods:

Between the government and a mood-public is of course many layers of mediation: from mainstream press to the blogosphere, in which words and narratives frame and contest not only who is this public (who counts as being part of this public) but the form of feeling. (p. 24)

Importantly, political discourse can strategically attach public moods to particular objects; 'a wavering impression of nervousness can straighten and strengthen its hold when we are given a face to be nervous about' (p. 26). For example, PISA shocks can be used by governments or the media to turn anxiety about individual advancement into public feelings attached to a problematic object such 
as curriculum or teacher quality, which can manifest, for example, as political demands for curriculum reform or a focus on quality teachers.

While the events that we are interested in here are often described in punctual terms as shocks, we argue that a sense of crisis has become the new ordinary-a mood of heightened anxiety-in an age where people are confronted with narratives of failing economic systems, a changing climate, terrorism, dramatic technological change and so on. Moreover, we are experiencing a shifting balance between data and facts, with the former being given in increasing volume, while the means to establish the latter-consensus concerning what the data show-are diminishing. This is the tension that animates the 'post-truth' age, and it plays out at the level of public sensation and sensemaking.

The news about the recent past and the pressures of the near future demand constant emergency cleanup and hyperspeculation about what it means to live in the ongoing present among piles of cases where things didn't work out or seem to make sense, at least not yet.... The affective structure of the situation is therefore anxious and the political emotions attached to it veer wildly from recognition of the enigma that is clearly there to explanations that make sense, the kind of satisfying sense that enables enduring. (Berlant, 2011, p. 225)

Analysing the interface between media reports about educational performance on PISA and the individual and collective subjectivities that have become sites of existential politics requires attention to how people make sense of what is presented as a punctuating crisis, in order to go on in conditions of ordinary crisis, coloured in this case by anxiety about educational opportunity structures and the future of the national economy.

\section{Methodological note}

The two cases that we analyse share important similarities and differences. Australia and Canada are both federal systems in which schooling is the responsibility of states and provinces. Both countries have participated in PISA since it was first implemented in 2000 and both countries oversample to enable analysis of performance at state and province level. Both countries have seen declining performance since 2000 and the pattern of declines across states and provinces is remarkably similar (see Table 1 and Table 2). However, Canada does not have the level of federal involvement in education that has been evident in Australia since the peak moment of Keynesian politics under the Whitlam Labor government (1972-1975) (Author, 2000; Wallner, 2014).

In the recent context of globalization, federal government involvement in schooling in Australia has strengthened, particularly from the time of the election of the Rudd Labor government in 2007. There is no federal education minister or federal department of education in Canada, and while there has been curriculum alignment across some provinces and territories, Canada does not have a national curriculum or national teacher standards. Canada does have national testing in the form of the Pan-Canadian Assessment Program (PCAP), which is overseen by the Council of Ministers of Education-Canada. PCAP provides a sample-based assessment of performance at a system-level. In contrast, Australia has a federal minister of education, a federal education department, and national approaches to testing, curriculum and teacher standards. The Australian National Assessment Program - Literacy and Numeracy (NAPLAN) is a census test that provides national data on system, school and student level performance. These differences - which are differences in the functioning 
of federalism - have proven to be one important factor in relation to the reception of PISA in both countries and its framing and impact in policy making.

The data analysed for the two cases are primarily newspaper articles published in Canada and Australia. A systematic search of articles relating to the OECD's PISA was conducted focusing initially on the newspaper of record in each country (The Globe and Mail, The Australian). In both cases additional documents that shaped media representations of PISA results were also collected and analysed. For the Canadian case, which focuses on Alberta, article searches were conducted in the Edmonton Journal and the Calgary Herald. These searches were conducted for the period from December 2013 until December 2016. PISA was first identified as a matter of concern by the Albertan media in January 2014. The analysis mainly focuses on a 44-part series of articles published in the Edmonton Journal from this time. Documents that shaped the public debate about mathematics curriculum in Alberta were also obtained from the website of the parent activist group, Albertans for Education (http://www.albertansforeducation.com/) website, including petition texts. For the Australian case, article searches included the following newspapers: Australian Financial Review, The Sydney Morning Herald and The Age. These searches were conducted for the period from January 2012 until December 2016. The narrative of declining performance that we focus on here first emerged in early 2012. Other documents analysed for this case include reports and a government white paper that prompted media coverage in relation to PISA and which provided a backdrop to the public debate._Articles included in the discussion of both cases below were selected based on their representativeness of key themes and messages in the broader corpus of articles.

We acknowledge the limitations to our approach of reading affect off of text; affect is not its 'sociolinguistic fixing' as an emotion with a conventional meaning that can be expressed in texts (Massumi 2002) and thus experience within the contexts of production of texts is important in order to appreciate something of the pre-subjective relational dynamics from which they emerged and in which they are received. The two authors have drawn on their experience in both the Canadian and Australian education policy contexts, including participating in public debate during the periods analysed in each case, to augment the analysis of the affective worlds for which the textual artefacts analysed below act as indexes. We recognise that the liminal nature of affect limits analytical possibilities, particularly in terms of evidencing claims about the specific dynamics of individual and collective experience. However, working at these limits can offer important glimpses into underexamined dimensions of policy making, political discourse and public mood.

\section{Case one: The great Canadian maths debate}

Our first case focuses on what the Edmonton Journal dubbed 'The Great Canadian Mathematics Debate' and the parent-led reform movement that arose in Alberta following the publication of PISA 2012 results. Mathematics was first assessed as a major domain of PISA in 2003 and it was the major domain for a second time in PISA 2012. The publication of the 2012 results in December 2013 provided the first opportunity properly to compare mathematics performance over time. Canada performed well in 2003 with a national average score of 532. All provinces performed at or above the OECD average. Alberta was the top-performing Canadian province with a score of 549, which placed it second only to Hong Kong. By 2012, the Canadian national average score had decreased to 518 , with all but two provinces-Quebec and Saskatchewan-showing statistically significant declines since 2003. Alberta received an average score of 517 in 2012, reflecting a decline of 32 points. Here we examine how Canada's declining performance gave rise to a sense among some Albertans that mathematics education was in crisis. 
[INSERT TABLE 1. PISA 2003-2012 performance in Canada and Canadian provinces]

Canada's mathematics performance on PISA 2012 made the headlines nationally. The Globe and Mail, which is arguably Canada's newspaper of record, reported on the day of the PISA release that 'Canada's fall in math-education ranking sets off alarm bells' (Alphonso, 2013). The editorial in the same issue was titled 'Quebec adds, Canada subtracts on its math scores' ("Quebec adds," 2013). The following day, The Globe and Mail shifted the attention to mathematics curriculum and the 'fuzzy' discovery mathematics that had been promoted in the collaborative approach to curriculum sponsored by the Western and Northern Curriculum Protocol (WNCP) (Craigen, 2013). Alberta, Manitoba, Saskatchewan, Nunavut, Yukon and Northwest Territories are signatories to the WNCP. An article published on 5 December again argued that Canada's declining mathematics performance should be attributed to a failed experiment in discovery mathematics (Yakabuski, 2013).

The seeds of the response in Alberta were sown with this initial national mediatisation of the PISA results, particularly the blaming of discovery math curriculum, however coverage of the results was delayed in Alberta. Neither the Calgary Herald or the Edmonton Journal ran articles on 3 December and neither published pieces that directly addressed PISA in the weeks that followed (although the Edmonton Journal did publish two articles on class sizes referencing the OECD and its Director of Education and Skills, Andreas Schleicher). In comparison to the national coverage, publicity regarding the PISA results was negligible in Alberta's two main cities in the days that followed the data release. However, this began to change early in the following year.

On 21 January 2014, David Staples, a columnist for the Edmonton Journal, published the first article in what would become a 44-part series titled, 'The Great Canadian Math Debate'. The article focused on Dr Nhung Tran-Davies, a medical General Practitioner and parent who, on 11 December 2013, started an online petition protesting the math curriculum in Alberta (Staples, 2014). The petition was titled 'Back to basics: Mastering the fundamentals of mathematics', and it began by explaining that Tran-Davies, '[a]s a mother of three young children who are just entering into their primary years of education', found the results of PISA 2012 'extremely disturbing, alarming and unsettling' (TranDavies, 2013). Notable here is the emotive language employed by Tran-Davies to describe her response to the PISA results. The petition attracted more than 18,000 signatures and was followed by another that garnered a few thousand more. A website setup to support the movement started by Tran-Davies (http://www.albertansforeducation.com/) explains that support for a 'back to basics' mathematics curriculum gathered momentum during 2014 and has had an impact on curriculum and policy discussions in Alberta. Recent policy announcements by the Albertan government corroborate this claim.

Tran-Davies' alarm about the mathematics curriculum sparked the media attention on PISA in Alberta. Staples' series of articles in the Edmonton Journal sustained this attention and PISA is mentioned frequently in these pieces. One early article included 73 statements from people who signed the petition (Staples, 2014). Twenty-three of these statements include a reference to paying for out of school tuition or teaching math at home in order to compensate for shortcomings in the mathematics curriculum. For example:

As the mother of a daughter in Grade 6, I am deeply concerned about the direction of math education. My daughter's lack of the basics (multiplication, division, addition) is having a negative impact on her education and her emotional state. I am supplementing 
her education with tutoring which, at $\$ 50-60 /$ hour, is challenging as a single mother. (Kathy)

Our son is failing miserably! At home we have been doing math and he says his father \& I do it wrong. This "be free to explore" system of education has got to stop! We now have to pay $\$ 10,000$ per year at a private school to give our kids the education WE received!! (Romy)

Many of the articles describe emotional responses to the math curriculum, such as the anxiety that some students experience learning discovery math at school. Other statements describe feelings of frustration and anger directed at the government. For example:

My 12-year-old son suffers anxiety and is stressed to the point he will no longer go to school due to the math. We are now driving him 2 hours to the Sylvan Learning Center where we can hopefully bring back his confidence. (Tammy)

My children have struggled with the new math and I am frustrated to know that I'm going to have to somehow "fix" a problem I didn't create, a problem that constitutes a betrayal, by the government, of parents and teachers. (Nicola)

The statements collected in the article span a range of views, from parent's anxiousness about their child's academic success to students who dislike aspects of their schooling and employers dissatisfied with the skills of their young workers. The public that emerged here make a 'satisfying sense', to borrow from Berlant, of changing educational opportunity structures and social structures more broadly. The comments solicit the reader to share the feelings expressed in the article and encourage the emergence of a public mood around concern about mathematics curriculum. David Staples and the Edmonton Journal clearly leveraged this mood to sustain an audience for articles lamenting mathematics performance in Alberta.

A number of issues demand analytical attention in this case. Firstly, the sense of crisis in Alberta coalesced around mathematics curriculum rather than as an immediate response to the release of PISA results. The PISA 2012 results and the public campaigning by Tran-Davies catalysed the feelings of anxiety, frustration and betrayal expressed by petitioners, but references to PISA or falling behind other nations in mathematics performance are rare in the reported comments of petitioners. Second, there is strong emphasis on the private costs of compensating for 'failed' curriculum. The concerns of parents about mathematics curriculum register a sense that the government has broken its promises in relation to the education of their children. Moreover, a generalised anxiety about change, in a province that only recently removed one the longest standing democratically elected governments anywhere, and the economic fortunes of which are subject to the vicissitudes of the global oil market, is expressed in the desire for 'back to basics' curriculum. Third, the reporting of this event and the campaign led by Tran-Davies gave people's private concerns a collective dimension as a public mood about schooling in Alberta.

In December 2016, on the day that PISA 2015 results were released, the Albertan Government bizarrely announced a package of reforms to improve math performance in schools. Alberta placed second in the world for science performance, which was the major domain assessed in PISA 2015, and also ranked highly in reading $\left(3^{\text {rd }}\right)$ and mathematics $\left(18^{\text {th }}\right)$. Yet, the government's response was 
to focus on marginal decline in the mathematics score (from 517 in 2012 to 511 in 2015) and to announce a package of reforms that spoke more directly to the anxieties produced by the previous round of PISA than the most current evidence generated by the programme. In this case, we can see how reform of mathematics curriculum in Alberta has been much more closely linked to modulations of the affective worlds of certain publics, by parent activist groups and journalists, than to evidence generated by international large-scale assessments.

\section{Case two: Australia's ongoing PISA shock}

Our second case focuses on Australia's PISA shock, which was a response to Shanghai's stellar performance on PISA 2009 and Australia's declining performance over time. This shock was precipitated and strengthened by a think tank report and a commissioned consultancy report on Australia's 2009 performance as compared with nations in East Asia, and specifically with Shanghai. There was something of a delay in the evocation of this shock; it did not emerge immediately following the release of PISA 2009 results in December 2010, but later in 2011 and 2012 as the analysis here will demonstrate. The affective effect was that a punctuated crisis became translated into a public mood in respect of schooling in Australia.

From the first round of PISA in 2000 through to the second and third rounds in 2003 and 2006, Australia performed well with limited, but very positive, media coverage of this performance (Author, 2016, pp. 6-7). In PISA 2012, the results for which were released in December 2013, Australia's performance declined: a 7 point drop in science, a 16 point decline in reading, and a 29 point drop in mathematics. Importantly, in PISA 2012 mathematics was the major domain and attention focused on trends in this domain since 2003. There was much negative media coverage. We will argue that the political and media response was a continuation of a policy narrative and an affective response that was established in the wake of PISA 2009 performance. It is the response to PISA 2009 results, released in 2010, that will be the main focus here.

[INSERT TABLE 2. PISA 2003 - 2012 performance in Australia and Australian states and territories]

Shanghai-China performed outstandingly well on PISA 2009, even out-performing the PISA poster child to that point, Finland. Shanghai scored 556 in reading (Finland 536; Australia, 515); 600 in mathematics (Finland 541; Australia 514) and 575 in science (Finland 554; Australia 527). Australia's performance was still well above the OECD averages, but decline from 2006 and the top performance of Shanghai, along with the fact that Singapore, Korea and Japan also outperformed Australia, aroused anxiety. There was a spike in media coverage of PISA 2009 following the release of the results in late 2010. However, the largest spikes in coverage came in 2011 and 2012 (Author, 2016), before the release of PISA 2012 results.

Here we see a double impact of PISA 2009 with the second and greater impact being produced by the publication of two reports: one by the consultancy firm, the Nous Group, the other by a think tank, the Grattan Institute. Both reports received extensive media coverage in 2011 and 2012 (see Author, 2013, pp. 477-479; Author, 2016). During 2011, the Prime Minister, Julia Gillard, appointed a committee to review school funding, chaired by prominent businessman, David Gonski. The review commissioned research from the Nous Group, which subsequently provided a report to the committee, entitled, Schooling Challenges and Opportunities: A Report for the Review of Funding for Schooling Panel (Nous Group 2011). The report compared Australia's schooling with other high performing national systems and began by noting that Australia was in danger of 'falling behind' 
Asian schooling systems that had out-performed Australia on PISA 2009, namely, Shanghai, Korea, Hong Kong and Japan. This received considerable media coverage, with the notion of 'falling behind' gaining particular affective resonance. During 2012, the government commissioned a White Paper, Australia in the Asian Century, which inter alia called for school reform because of Australia's declining performance on PISA and the very strong performance on the tests of Australia's Asian neighbours (Commonwealth of Australia, 2012). The Nous Group report and the White Paper received considerable media coverage.

The influential think tank, the Grattan Institute, released a report in early 2012 called, Catching Up: Learning from the Best School Systems in Asia (Jensen et al., 2012). The Grattan Institute had held a roundtable in late 2011 and this was attended by the Australian Prime Minister and federal education minister, education academics from Shanghai, Singapore, Hong Kong and Korea, and the Director of Education and Skills at the OECD. The report was released following the roundtable. The Shanghai schooling system is the focus of much of the report and was also the target of an opinion piece written by Ben Jensen, lead author of the report, which was published in the national newspaper, The Australian (Jensen, 2012). This report generated much media coverage. The Sydney Morning Herald suggested PISA 2009 results were a 'wake-up call' for Australia (Harrison, 2012). In a front page, headlined story in The Australian newspaper (Franklin, 2012), the Prime Minister Julia Gillard asserted that Australia had to 'win the education race'. The Prime Minister continued in this article: 'four of the tip five performing school systems in the world are in our region and they are getting better and better'. Linked to a human capital framing of schooling policy, the Prime Minister added that she did not want Australia school students to end up as 'workers in an economy where we are kind of the runt of the litter in our region and we've slipped beyond the standards and the high-skill, high wage jobs are elsewhere in our region'.

All of the reports, media coverage and political responses were indicative of Australia's PISA shock, an affective articulation of concerns about Australia's comparative performance on PISA 2009. One outcome of these deep concerns was the Gillard government setting a legislative goal of Australia being in the top five on PISA by 2025. We see in all of the media coverage, and in the political responses, the generation of a narrative of decline in Australian schooling that has continued though to this day, strengthened by media coverage and political responses to continuing decline of Australia's performance on PISA. This narrative has again been very evident in media coverage in December 2016 of Australia's 2015 PISA results, including headlines such as: 'Australian school students two years behind world's best performing systems' (Munro \& Bagshaw, 2016); 'Teenagers fall year behind internationally in maths' (Balogh, 2016); and 'Why Australia's PISA results are a catastrophe' (Buckingham, 2016).

There were several important contextual factors in this particular case. Australia has always taken the OECD and its work very seriously, especially but not exclusively in education. Two heads of education at the OECD have been Australian academics. Australia sees real significance in the OECD's work, given its standing as a mid-range world power. A second significant contextual factor was the rise of what has been called the 'Asian century', which was the backdrop to the White Paper mentioned above. Australia's economic future is closely tied to that of Asia and especially China. While Australia is still something of a European outpost in an Asian environment (though that is changing through contemporary migration patterns), Australia's future prosperity is tied very much with Asia. This is a narrative that was strongly held by federal Labor governments in Australia from 2007 to 2013. 'Falling behind' Asian schooling systems on PISA is disjunctive with this imagined 
future. A third significant contextual factor is the significance of education reform to the federal Labor government's policy agenda after their election in 2007 under Kevin Rudd as Prime Minister, with Julia Gillard as education minister and subsequently Prime Minister (Gillard saw herself as an 'education Prime Minister'). These federal Labor governments (2007-2013) gave great policy and funding priority to what they referred to as their 'Education revolution', as a way of ensuring equality of educational opportunity and the future prosperity of the nation. We would note as well that in the functioning of Australian federalism in schooling PISA has become high stakes for the federal minister for education; Australia's PISA performance demands media and policy responses and as such evokes a lot of national media attention. So, there was heavy political and emotional commitment to education as central to meritocracy and social mobility and also vital to ensuring a future vibrant economy that provided adequately for all with a continuing high standard of living. The decline in performance on mathematics and science in PISA and responses to this also must be seen in the context of strong government policy focus on STEM in schools. Furthermore, PISA has become more significant in policy terms over each cycle and has also become more significant in the education work of the OECD itself, including as a prototype for subsequent test developments at the OECD (Author, 2014a). Australia's apparent decline in performance on PISA 2009 was situated within these particular contexts and contributed powerfully to an ongoing narrative of decline. The response to PISA 2009 was in effect, affective, and was expressed as deep anxiety about Australia's future as a nation.

Interestingly, subsequent political discourse about Australian schooling has almost detached this narrative of decline from PISA results and it has been used as the raison d'etre for whatever schooling reforms federal governments have put in place. This has been particularly so with conservative governments and ministers of education subsequent to the defeat of the federal Labor government in 2013. Labor had accepted the recommendations of the Review of Funding for Schooling (known colloquially as the Gonski Review) for a needs-based approach, but which was modified in the context of the lead-up to the 2013 federal election. The subsequent Coalition conservative government reneged on their election promise to commit to needs-based funding, but strengthened a narrative of school decline. They articulated this narrative with the assertion that Labor's additional funding for schools did not result in improvement in student performance (citing PISA 2012 and 2015 results), which quickly morphed into the claim that 'funding does not matter'. Accompanying this has been a focus on quality teachers and more autonomy for school principals as forms designed to redress declining performance. For example, shortly after the election of the Coalition federal government in 2013, the new federal minister for education, Christopher Pyne, was reported as saying, 'Standards - not - money is the main issue facing schools', 'in a bid to steer the national debate away from school funding to a focus on teaching and student results' (Ferrari, 2013). Further, 'The issue in education is not a lack of money... The argument around teaching shouldn't be about industrial relations, it should be around: "Are our teachers as high a standard as they possibly could be, and if they aren't, how do we get them to that point?"' (p.5). This decontextualized focus on teachers was set against the government's concern with the extent of the budget deficit and the need for 'budget repair'.

Here we have shown how the 2009 PISA shock generated an affective response linked to concerns about the nation's economic future as a high-skill, high wage economy and the need for expenditure restraint and budget repair. Through to the present, these concerns have continued and strengthened, but are now manifest as a more generalized narrative of decline that is detached to 
some extent from PISA results, but exponentially enhanced during periods of reporting of international assessment results. For example, the reporting of the Trends in International Maths and Science (TIMSS) results a week before the release of 2015 PISA results on 6 December, 2016, also reinforced this narrative. For example, in a story in The Age (1 December, 2016) concerning. Australia's flat-lining on TIMSS, the current federal education minister was reported in this story as being 'embarrassed for Australia', because Australia had fallen behind Kazakhstan and Slovenia in the rankings.

This case has demonstrated that politicians, think tanks and journalists are aware that the public sphere is an affective world and that modulating affect is important in selling contemporary policy reforms, policy ideas and media products. As we have shown, selective use of the PISA data is utilized in constructing a narrative of decline, which sees a punctuated crisis - Australia's response to Shanghai's 2009 PISA performance - transmogrify into an ongoing, public modd, playing on national anxieties and insecurities that are central in the contemporary structure of feeling.

\section{Discussion and conclusion}

Our aim in this paper has been to analyse how the mediatization of PISA results within nations can (a) generate and shape the affective worlds of publics concerned with education and (b) become important catalysts for policy reform. Affective modulations are utilised by politicians as the backdrop to the necessity of whatever reforms they seek to implement, and the media plays an important role in amplifying these modulations among various publics. Our argument is that PISA data often have less impact as evidence than as a catalyst for anxiety about educational performance and its implications for individual and collective futures. Rather than fulfilling the rationalist objective of providing evidence for policymakers, PISA data are often used to create public moods that can be used by politicians and other actors to legitimise reform agendas. Here we see the link between the affective effects of PISA data and post-truth politics in which emotions and beliefs can take political precedence over facts and rationality.

Our two cases demonstrate how different federal structures, in part, mediated the response to PISA in Canada and Australia. We do not claim that all of the differences between the two cases can be attributed to this factor, but rather that different federalisms led to publics emerging at different scales with different policy impacts. PISA has become high-stakes for ministers of education and the presence of a federal minister of education, and a Prime Minister with a strong policy focus on education, led to Australia's PISA shock occurring at a national level. Moreover, the results of PISA 2009 were released in the context of national reform agendas in education and much policy debate about the rise of China and Australia's place in the region. In contrast, Canada does not have a federal minister of education or a federal department of education. Thus, while there was national reporting of poor mathematics performance on PISA 2012, the crisis that occurred in Canada took place at the provincial level and pressure for reform was focused on the Albertan Government.

The different contexts of the two cases also led to differences in the kinds of affective responses catalysed by PISA. In Alberta, the crisis was produced by a parent-led activist movement for mathematics curriculum reform. Alberta is a wealthy, low taxing province that has performed very well in large-scale international assessments and the declines in PISA resonated at the level of individuals and families becoming concerned about declining standards and having to subsidise their child's education through out-of-school tuition. The public that emerged around this issue was provincial and the anxiety catalysed by PISA was attached by activists and journalists to an enduring 
'back to basics' narrative as the putative solution. In contrast, the response in Australia focused more strongly on the economic prospects of the nation given its geopolitical location adjacent to Asia. In this case, the anxiety provoked by PISA was more closely linked to senses of national identity and declining national economic prospects. Policy responses to this situation were then mediated by the political stance of the different political parties in power at the national level and through selective usage of PISA data. The narrative of school decline has also, in the Australian context, become a more generalized national mood that plays into an anxious structure of feeling about individual and collective futures.

Berlant (2011) argues that public spheres are affective worlds and in both cases examined here punctual crises modulated these worlds and were transformed into lingering public moods (Ahmed, 2014) about educational performance and quality. We have sought to demonstrate that these conceptual resources drawn from affect theory can help us to understand how affective worlds and public moods become a site of political intervention by governments and other actors who aim to create a perceived need for policy reform. We argue that in our present political moment globally, attention to the rhetorical use of proliferating data to modulate affective worlds, in order to justify political agendas, will become increasingly important. 


\section{References}

Author. (2016).

Author (2000).

Author (2013).

Author (2004).

Author (2015).

Author (2013).

Author (2014a).

Author (2014b).

Ahmed, S. (2014). Not in the mood. New Formations, 82, 13-28.

Alphonso, C. (2013, December 3). Canada's fall in math-education ranking sets off alarm bells. The Globe and Mail. Retrieved from http://www.theglobeandmail.com/news/national/education/canadas-fall-in-matheducation-ranking-sets-off-red-flags/article15730663/

Appadurai, A. (1996) Modernity at large: Cultural dimensions of globalization. Minneapolis: The University of Minnesota Press.

Anderson, B. (2006). Imagined communities: Reflections on the origin and spread of nationalism. Verso Books.

Balogh, S. (2016, December 7). Teenagers fall year behind internationally in maths. The Australian. Retrieved from http://www.theaustralian.com.au/national-affairs/education/teenagers-fallyear-behind-internationally-in-maths/news-story/a78fb05e594ec04b9c67b0c3a8b57a09

Berlant, L. (2005). The epistemology of state emotion. In A, Sarat (Ed.), Dissent in dangerous times (pp. 46-78). Ann Arbor: University of Michigan Press.

Berlant, L. (2011). Cruel optimism. Duke University Press: Durham \& London.

Berlant, L. (2016). The commons: Infrastructures for troubling times. Environment and Planning D: Society and Space, 34(3), 393-419.

Brøgger, K. (2016). The rule of mimetic desire in higher education: governing through naming, shaming and faming. British Journal of Sociology of Education, 37(1), 72-91.

Brogger, K. \& Staunæs, D. (2016). Standards and (self)implosion: How the circulation of affects accelerates the spread of standards and intensifies the embodiment of colliding, temporal ontologies. Theory \& Psychology, 26(2), 223-242.

Brown, P. (2003). The opportunity trap: education and employment in a global economy. European Educational Research Journal, 2(1), 141-179.

Brown, P., Lauder, H. and Ashton, D. (2011). The global auction: The broken promises of education, jobs and incomes. Oxford \& New York: Oxford University Press.

Buckingham, J. (2016, December 6) Why Australia's PISA results are a catastrophe. The Australian Financial Review. Retrieved from http://www.afr.com/opinion/columnists/why-australiaspisa-results-are-a-catastrophe-20161206-gt536q

Collins, R. (1979). The credential society: An historical sociology of education and stratification. New York: Academic Press.

Collins, R. (2013). The End of Middle-Class Work: No More Escapes. In Does Capitalism Have a Future?, edited by I. Wallerstein, R. Collins, M. Mann, G. Derluguian, and C. Calhoun, 37-69. New York: Oxford University Press.

Commonwealth of Australia (2012). Australia in the Asian Century. Australian Government: Canberra.

Craigen, R. (2013, December 4). Why does fuzzy math persist? It's a bonanza for consultants, publishers. The Globe and Mail. Retrieved from http://www.theglobeandmail.com/news/national/education/why-does-fuzzy-math-persistits-a-bonanza-for-consultants-publishers/article15763158/

Deleuze, G. (1990). The Logic of Sense. New York: Columbia University Press. 
Ferrari, J. (2013, September 28). Pyne puts focus on teaching standards. The Australian. Retrieved from http://www.theaustralian.com.au/national-affairs/pyne-puts-focus-on-teachingstandards/news-story/383860c30c4c787fd5cb3ad74b677464

Franklin, M. (2012, January 24). We risk losing education race, Julia Gillard warns. The Australian. http://www.theaustralian.com.au/national-affairs/education/we-risk-losing-education-racejulia-gillard-warns/news-story/a2dd64e2aa9e372429dfdfa7d001a166

Grek, S. (2009) Governing by numbers: The PISA 'effect' in Europe. Journal of Education Policy, 24(1), 23-27.

Harrison, D. (2012, February 17). A class above. The Sydney Morning Herald. Retrieved from http://www.smh.com.au/national/a-class-above-20120216-1tbq7.html

Jensen, B., A. Hunter, J. Sonneman, \& T. Burns. (2012). Catching up: Learning from the best school systems in East Asia. Melbourne: Grattan Institute.

Jensen, B. (2012, February 18). Shanghai success a lesson in delivery. The Australian. Retrieved from http://www.theaustralian.com.au/national-affairs/opinion/shanghai-success-a-lesson-indelivery/news-story/ad75f0172331596592c909d81781957d

Lury, C., Parisi, L., \& Terranova, T. (2012). Introduction: The becoming topological of culture. Theory, Culture and Society, 29(4-5), 3-35.

Martens, K. \& Niemann, M. (2013) When do numbers count? The differential impact of the PISA ranking and rating on education policy in Germany and the US. German Politics 22, 314-332. DOI: 10.1080/09644008.2013.794455

Massumi, B. (2002). Parables for the virtual: Movement, affect, sensation. Duke University Press.

Massumi, B. (2011). Semblance and Event (p. 23). Cambridge, MA: MIT Press.

Munro, K. \& Bagshaw, E. (2016, December 6). Australian school students two years behind world's best performing systems. The Sydney Morning Herald. Retrieved from http://www.smh.com.au/national/education/australian-school-students-two-years-behindworlds-best-performing-systems-20161206-gt4w8p.html Nous group. (2011). Schooling challenges and opportunities: A report for the Review of Funding for Schooling Panel. Melbourne: Nous Group.

OECD (2002) Educational Policy Analysis, Paris: OECD Publishing.

Pons, X. (2011). What Do We Really Learn from PISA? The Sociology of its Reception in Three European Countries (2001-2008). European Journal of Education, 46(4), 540-548.

Quebec adds, Canada subtracts on its math scores (2013, December 3). The Globe and Mail. Retrieved from http://www.theglobeandmail.com/opinion/editorials/quebec-adds-canadasubtracts-on-its-math-scores/article15748296/

Raco, M. (2009). From expectations to aspirations: State modernisation, urban policy, and the existential politics of welfare in the UK. Political Geography, 28(7), 436-444.

Ratner, H. \& Pors, J.G. (2013). Making invisible forces visible. Managing employees' values and attitudes through transient emotions. International Journal of Management Concepts and Philosophy, 7(3/4), 208-223.

Rizvi, F. \& Lingard, B. (2010) Globalizing Education Policy. London: Routledge.

Rosenberg, D. (2013). Data before the fact. In L. Gitelman (Ed.), "Raw data" is an oxymoron (pp. 1540). Massachusetts, MN: Massachusetts Institute of Technology Press.

Savage, G. \& O'Connor, K. (2015) National agendas in global times: Curriculum reforms in Australia and the USA since the 1980s. Journal of Education Policy. 30 (5): 609-630.

Staples, D. (2014, January 21). Why Nhung Tran-Davies, a mom and a small town family doctor, is leading the fight in Canada for better math education. Edmonton Journal. Retrieved fromhttp://edmontonjournal.com/news/local-news/why-nhung-tran-davies-a-mom-and-asmall-town-family-doctor-is-leading-the-fight-for-better-math-education

Staples, D. (2014, January 27). Nhung Tran-Davies to take anguished and angry parental concerns about discovery math to Alberta Education officials on Tuesday. Edmonton Journal. Retrieved from http://edmontonjournal.com/news/local-news/dont-experiment-with-my- 
children-parents-losing-faith-in-alberta-public-school-system-over-its-voodoo-mathcurriculum?cid=dlvr.it-twitter-edmontonjournal

Staunæs, D. (2011). Governing the potentials of life itself? Interrogating the promises in affective educational leadership. Journal of Educational Administration and History, 43(3), pp. 227247.

Steiner-Khamsi, G. (2003). The politics of League Tables, Journal of Social Science Education, (1): 1-6. Retrieved from http://www.jsse.org/index.php/isse/article/view/470

Yakabuski, K. (2013, December 5). The damaging legacy of discovery learning. The Globe and Mail. Retrieved from http://www.theglobeandmail.com/opinion/the-damaging-legacy-ofdiscovery-learning/article15768057/

Tran-Davies, N. (2013) https://www.change.org/p/back-to-basics-mastering-the-fundamentals-ofmathematics.

Waldow, F., Takayama, K., \& Sung, Y. K. (2014). Rethinking the pattern of external policy referencing: media discourses over the "Asian Tigers" PISA success in Australia, Germany and South Korea. Comparative Education, 50(3), 302-321.

Wallner, J. (2014) Learning to School: Federalism and Public Schooling in Canada. Toronto: University of Toronto Press. 